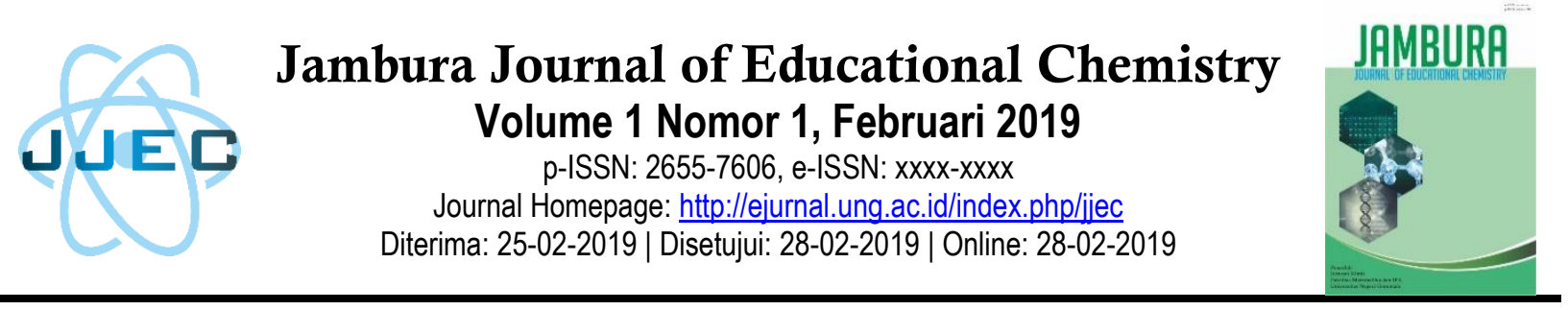

\title{
Validitas Perangkat Pembelajaran Materi Ikatan Kimia berbasis Model Pembelajaran Pemaknaan untuk Melatihkan Sensitivitas Moral Siswa SMA
}

\author{
Alfikry Gonibala1, Masrid Pikoli², Akram La Kilo³ \\ ${ }^{1,2}$ Prodi Pendidikan Kimia, Jurusan Kimia, Fakultas Matematika dan IPA, Universitas Negeri Gorontalo \\ 3Prodi Kimia, Jurusan Kimia, Fakultas Matematika dan IPA, Universitas Negeri Gorontalo \\ e-mail: ${ }^{1}$ alfikrygonibala@gmail.com
}

\begin{abstract}
Abstrak
Penelitian ini merupakan penelitian pengembangan yang bertujuan untuk menghasilkan perangkat pembelajaran materi ikatan kimia berbasis model pembelajaran pemaknaan yang valid untuk melatihkan sensitivitas moral siswa SMA. Pengembangan perangkat pembelajaran menggunakan model 4D (Four D). Hasil penelitian yang didapatkan, yaitu perangkat pembelajaran yang dikembangkan meliputi buku siswa, RPP, LKPD, dan angket sensitivitas moral telah memiliki validitas dengan kategori sangat valid. Hasil penelitian telah menunjukkan bahwa perangkat pembelajaran materi ikatan kimia berbasis model pembelajaran pemaknaan valid untuk melatihkan sensitivitas moral siswa SMA.
\end{abstract}

Kata kunci: Perangkat Pembelajaran, Model Pembelajaran Pemaknaan, Sensitivitas Moral

\section{PENDAHULUAN}

Pendidikan merupakan aspek utama dalam mengembangkan diri manusia dan sebagai jembatan untuk meningkatkan pengetahuan. Di era yang semakin modern dengan berbagai fasilitas yang memudahkan untuk mengakses pengetahuan, maka pendidikan perlu kiranya diformulasi untuk menyesuaikan tuntutan perkembangan zaman, sehingga sesuai dengan kebutuhannya (Ormrod, 2002). Kebijakan nasional pembangunan karakter bangsa disusun sebagai pelaksanaan amanat UU RI No. 17 Tahun 2007 tentang Rencana Pembangunan Jangka Panjang Nasional Tahun 2005 - 2025. Keberhasilan pembangunan karakter bangsa ditandai dengan terwujudnya karakter bangsa yang tangguh, kompetitif, berbudi pekerti, bermoral, bertoleran, bergotong royong, patriotik, dinamis, berbudaya, dan berorientasi iptek berdasarkan pancasila dan dijiwai oleh iman dan takwa kepada
Tuhan Yang Maha Esa (Kemendiknas, 2010). Masalah sekarang adalah siswa dalam penerimaan ilmu di sekolah hanya berfokus pada pengetahuan umum saja dan nilai spiritual tentang adab-adab keislaman tidak didapatkan oleh mereka. Contohnya adalah membolos, meninggalkan pelajaran, datang terlambat, merokok, mengambil uang dan HP teman, mengganggu pelajaran, bertengkar, mengganti nilai raport, pacaran, hamil diluar nikah dan memotret teman yang sedang ganti pakaian di kamar mandi terjadi di sekolah (Sumarni dkk., 2012).

Kurikulum 2013 memberikan arahan bahwa pembelajaran sains harus bertumpu pada keaktifan siswa dan mereka harus mendapatkan pengalaman nyata dalam proses pembelajarannya. Setiap pembelajaran hendaknya dapat membentuk moral dan kepribadian siswa seperti jujur, bertanggung jawab, disiplin dan meningkatkan 
ketakwaan mereka terhadap Tuhan Yang Maha Esa (Kemendikbud, 2012). Pendekatan pembelajaran yang sesuai dengan kurikulum 2013 untuk dapat memperbaiki moral siswa salah satunya adalah model pembelajaran pemaknaan. Model pembelajaran pemaknaan merupakan model pembelajaran melalui contoh dan teladan keterkaitan peristiwa, gejala atau fenomena yang berpotensi dapat dijadikan model di dalam pembelajaran yang bertujuan untuk mengajarkan sikap positif, akhlak mulia, dan budi pekerti di samping aspek akademiknya (Sudiyono dkk., 2015). Begitu pula perangkat pembelajaran yang digunakan hendaknya dapat memuat arahan tersebut sehingga mampu membantu siswa belajar mandiri dan mengembangkan diri serta dapat terbentuk karakter dan moral yang baik.

Dalam suatu proses belajar mengajar, kemampuan siswa dalam memahami suatu konsep sangat dipengaruhi oleh kemampuan guru yaitu salah satunya dalam menyiapkan perangkat pembelajaran yang variatif. Perangkat pembelajaran yang variatif adalah perangkat pembelajaran yang dapat memanfaatkan sumber belajar yang tersedia di lingkungan sekolah dan dapat dijangkau oleh guru ataupun siswa (Prastowo, 2011). Adapun salah satu sumber belajar yang dapat disusun menjadi salah satu perangkat pembelajaran adalah nilai-nilai moral yang diintegrasikan dengan ilmu kimia sebagai model pengajaran sikap positif, akhlak mulia, dan budi pekerti.

Pembelajaran dengan sistem pengajaran islam telah mampu meningkatkan karakter siswa, salah satunya hasil penelitian Ismail (2013) yang mampu meningkatkan kedisiplinan siswa. Hamidi dkk. (2010) secara lebih luas membuktikan pembelajaran berbasis nilai-nilai Al-Quran dapat meningkatkan kesehatan mental siswa sehingga dengan ini diharapkan memicu prestasi mereka.

Kimia sebagai salah satu cabang dari Ilmu Pengetahuan Alam (IPA) terdapat berbagai gejala/fenomena yang amat menarik dan berpotensi untuk menjadi model sikap moral. Untuk mengajarkan sikap moral membutuhkan contoh dan teladan, tentang bagaimana sikap moral itu dilakukan. Konsep kimia menyediakan model yang dapat ditiru oleh siswa jika guru membantu siswa untuk menangkap makna. Internalisasi dilakukan terhadap gejala/fakta/konsep tertentu dan mengaitkannya dengan sikap moral yang terdapat didalam Al-Quran.

Hasil penelitian penerapan model pembelajaran pemaknaan pada bidang studi kimia siswa SMK menunjukkan bahwa penerapan model pembelajaran pemaknaan pada pembelajaran kimia dapat mengembangkan karakter jujur, disiplin, dan kerjasama siswa (Yuliani dkk., 2012). Penelitian lainnya dikemukakan oleh Pertiwiningrum dkk. (2013) melakukan penelitian di SMA pada mata pelajaran biologi, memperoleh hasil bahwa model pembelajaran pemaknaan dapat melatihkan sikap moral siswa dan dapat menanamkan nilai-nilai karakter terhadap siswa.

Berdasarkan latar belakang masalah yang merujuk pada pendapat tokok-tokoh pendidikan, tujuan kurikulum 2013, dan berbagai hasil tentang perbaikan nilai moral kepada peserta didik, maka dilakukan penelitian tentang "Validitas Perangkat Pembelajaran Materi Ikatan Kimia Berbasis Model Pembelajaran Pemaknaan untuk Melatihkan Sensitivitas Moral Siswa SMA."

\section{METODE PENELITIAN}

Penelitian ini merupakan penelitian pengembangan yaitu mengembangkan suatu perangkat pembelajaran materi ikatan kimia berbasis model pembelajaran pemaknaan untuk melatihkan sensitivitas moral siswa SMA. Proses pengembangan perangkat pembelajaran mengacu pada pengembangan yang disarankan oleh Thiagarajan dkk. (1974) yang disebut Model 4D (four D Model) yaitu define, design, development, dan disseminate.

Subjek dalam penelitian ini adalah perangkat pembelajaran materi ikatan kimia berbasis model pembelajaran pemaknaan untuk melatihkan sensitivitas moral siswa SMA yang memenuhi kriteria validitas

\section{Instrumen dan Teknik Pengumpulan Data}

Instrumen yang digunakan dalam penelitian ini adalah instrumen untuk mengukur validitas perangkat pembelajaran yang dikembangkan. Validitas perangkat pembelajaran diukur dengan menggunakan lembar penilaian atau lembar validasi yang sudah dinyatakan valid berdasarkan hasil penilaian tim ahli. Lembar 
validasi yang digunakan dalam penelitian ini terdiri dari (1) lembar validasi buku siswa, (2) lembar validasi RPP, (3) lembar validasi LKPD, dan (4) lembar validasi angket sensitivitas moral siswa

\section{Teknik Analisis Data}

Analisis data dalam penelitian ini menggunakan teknik analisis kuantitatif dan analisis data yang dilakukan yaitu analisis data validitas perangkat pembelajaran.

\section{HASIL DAN PEMBAHASAN}

\section{a) Hasil Penelitian}

Perangkat pembelajaran yang telah dihasilkan terdiri atas Buku Siswa, Rencana Pelaksanaan Pembelajaran (RPP), Lembar Kerja Peserta Didik (LKPD), dan angket sensitivitas moral. Dalam penelitian perangkat pembelajaran yang dikembangkan didasarkan pada model pembelajaran pemaknaan.

Kualitas rancangan perangkat pembelajaran yang dihasilkan merujuk pada tiga kategori yaitu validitas. Validitas diperoleh melalui penilaian ahli untuk menilai validitas perangkat pembelajaran yang telah dibuat.

Penilaian terhadap perangkat pembelajaran yang dikembangkan berdasarkan model pembelajaran pemaknaan dilakukan oleh tiga orang ahli yang menilai Buku Siswa, Rencana Pelaksanaan Pembelajaran (RPP), Lembar Kerja Peserta Didik (LKPD), dan Angket sensitivitas moral. Uji validasi ini bertujuan untuk mengetahui apakah perangkat yang dibuat layak atau tidak untuk digunakan.

\section{Hasil Validasi/Penilaian Ahli terhadap Buku Siswa, RPP, dan LKPD}

Kriteria yang digunakan untuk menyatakan bahwa buku siswa memenuhi kriteria validitas yang baik adalah apabila rata-rata penilaian ahli untuk setiap aspek berada dalam kriteria minimal valid dengan nilai persentase $69 \%$ - 84\%. Hasil penilaian ahli terhadap buku siswa disajikan pada Gambar 1 .

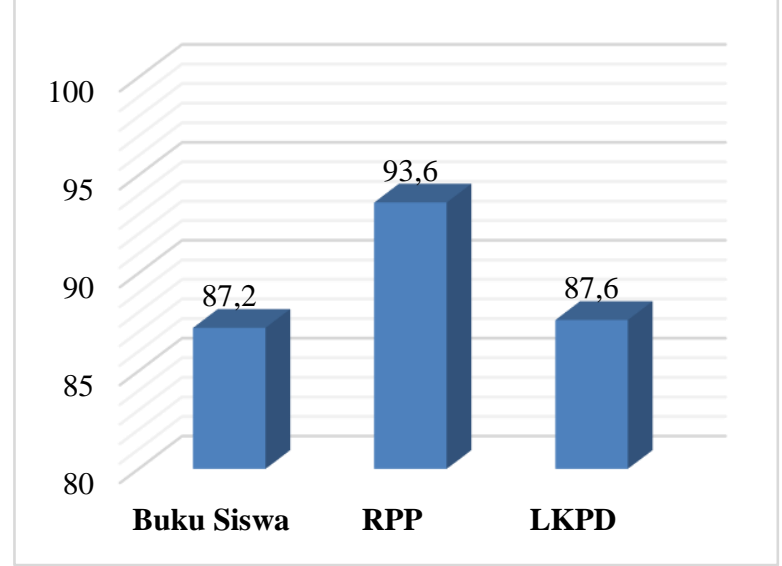

Gambar 1. Penilaian Ahli Terhadap Buku Siswa, RPP, LKPD

Berdasarkan Gambar 1 penilaian ahli terhadap Buku Siswa, RPP, dan LKPD keseluruhan memiliki skor rata-rata di atas $84 \%$ dengan kategori sangat valid (SV) sehingga layak digunakan dalam pembelajaran. Semua ahli menyatakan bahwa Buku Siswa, RPP, LKPD yang dikembangkan sesuai dengan model pembelajaran pemaknaan dan layak untuk digunakan dalam pembelajaran.

\section{Hasil Validasi/Penilaian Ahli terhadap Angket Sensitivitas Moral}

Penilaian ahli terhadap instrumen tes sentivitas moral dilakukan dengan memberikan pernyataan "ya" (valid) dan "tidak" (tidak valid), serta memberikan kesimpulan akhir penilaian, apakah layak atau tidak layak untuk digunakan dengan memberikan pernyataan layak digunakan (LD), layak digunakan dengan perbaikan (LDP), atau tidak layak digunakan (TLD). Hasil penelitian ahli terhadap angket sensitivitas moral didapatkan bahwa semua butir soal memperoleh penilaian ahli dengan kategori validitas valid, baik ditinjau dari aspek materi, konstruksi, maupun aspek bahasa. Fakta ini mengindikasikan bahwa semua butir tes yang dikembangkan untuk konsep ikatan kimia mempunyai derajat validitas yang baik. Penilaian ini diperoleh setelah perbaikan sesuai saran-saran ahli.

Uji coba angket sensitivitas moral dilakukan pada siswa kelas X IPA 2 di SMA Terpadu Wira Bhakti dengan jumlah 22 siswa. Data hasil uji coba instrumen tes digunakan untuk menentukan validitas dan reliabilitas tes. Adapun hasil analisis uji validitas dan reliabilitas diuraikan sebagai berikut. 


\section{1) Uji Validitas}

Perhitungan uji validitas angket sensitivitas moral dilakukan untuk menguji kesahihan setiap item soal. Hasil uji validitas angket sensitivitas moral didapatkan bahwa seluruh item soal memiliki nilai r-hitung yang lebih besar dari nilai r-tabel, sehingga item-item soal tersebut layak digunakan sebagai alat ukur dalam penelitian.

\section{2) Uji Reliabilitas}

Pengujian reliabilitas dilakukan dengan cara menguji coba angket dan kemudian dianalisis dengan menggunakan metode alpha cronbach. Nilai reliabilitas angket sensitivitas moral yang didapatkan yaitu 0,94 . Hasil ini menujukkan bahwa angket sensitivitas moral ini memiliki kategori derajat reliabilitas tinggi karena nilainya melibihi dari nilai 0,80 .

\section{b) Pembahasan}

Proses pengembangan perangkat pembelajaran materi ikatan kimia berbasis model pembelajaran pemaknaan mengacu pada model pengembangan Thiagarajan (1974) yaitu model pengembangan 4D yang direduksi menjadi 3D meliputi pendefinisian (define), perancangan (design), dan pengembangan (development).

\section{a. Pendefinisian (Define)}

Tahap pendefinisian (define) meliputi kegiatan analisis kurikulum, analisis siswa dan analisis materi. Kegiatan ini diawali dengan melakukan observasi dan wawancara dengan guru mata pelajaran kimia kelas X di SMA Negeri 1 Suwawa terkait ketersediaan perangkat pembelajaran yang ada terhadap materi ikatan kimia, diperoleh bahwa secara umum perangkat pembelajaran yang tersedia adalah buku paket dan lembar kerja peserta didik (LKPD) yang berisi materi dan latihan soal yang belum dapat memfasilitasi siswa dalam meningkatkan pengetahuan moral siswa dan belum dapat melatihkan sensitivitas moral siswa terhadap suatu konsep kimia.

Analisis kurikulum yang dilakukan meliputi analisis materi pokok, Kompetensi Inti (KI) dan Kompetensi Dasar (KD) sesuai dengan kurikulum 2013 pada materi ikatan kimia untuk menjabarkan beberapa indikator sebagai acuan dalam penyusunan perangkat pembelajaran.
Analisis siswa dilakukan untuk melihat karakteristik siswa dalam proses pembelajaran. Karakteristik ini meliputi kemampuan akademik yang dimiliki, dan kemampuan siswa dalam kerja kelompok, serta pengetahuan moral siswa.

Berkaitan dengan kemampuan kerja kelompok, berdasarkan pengamatan peneliti bahwa pada pelaksanaan pembelajaran, terlihat masih ada siswa yang kurang aktif, kurang adanya kerja sama dalam kelompok, mengandalkan teman dalam menyelesaikan tugas serta banyak yang hanya bermain saat pembelajaran berlangsung. Sedangkan untuk pengetahuan moral, terlihat pengetahuan moral siswa masih kurang dalam mengikuti pembelajaran. Hal ini disebabkan tidak adanya buku siswa dan lembar kerja peserta didik yang dapat meningkatkan pengetahuan moral sehingga pembelajaran hanya terfokus pada kemampuan kognitif saja.

Menurut Piaget (Budiningsih, 2004) kemampuan berpikir siswa pada usia 16-17 tersebut berada dalam periode operasional formal. Dalam analisis kognitif diasumsikan bahwa siswa telah memasuki tahap perkembangan operasi formal. Pada tahap perkembangan tersebut siswa telah memiliki kecakapan berpikir ilmiah dengan tipe hipothetico-dedutive dan inductive sudah mulai dimiliki anak, dengan kemampuan menarik kesimpulan, menafsirkan dan mengembangkan hipotesa. Hasil analisis siswa tersebut dijadikan dasar dalam menyusun perangkat pembelajaran yang akan dikembangkan.

Analisis materi ditujukan untuk, memilih dan menetapkan, merinci dan menyusun secara sistematis materi ajar yang relevan untuk dikembangkan dan diajarkan. Materi pelajaran yang digunakan dalam penelitian ini adalah materi ikatan kimia.

\section{b. Perancangan (Design)}

Pada tahap perancangan (design), dilakukan penyusunan perangkat pembelajaran materi ikatan kimia berbasis model pembelajaran pemaknaan yang terdiri dari buku siswa, Rencana Pelaksanaan Pembelajaran (RPP), Lembar Kerja Perserta Didik (LKPD), dan instrumen angket sensitivitas moral siswa yang nantinya akan menghasilkan desain awal draft 1. Pada tahap ini peneliti mengintegrasikan suatu konsep kimia 
dengan pengetahuan moral berupa Al-Quran dan Hadits yang dijadikan sebagai model dalam pembelajaran pada perangkat pembelajaran terutama buku siswa.

\section{c. Pengembangan (Development)}

Pada tahap ketiga adalah tahap pengembangan (development) yang meliputi telaah validasi oleh para validator dan uji coba terbatas. Hasil penilaian dari validator ini selanjutnya digunakan untuk peneliti untuk merevisi perangkat pembelajaran draft 1. Hasil revisi perangkat pembelajaran draft 1 menghasilkan perangkat pembelajaran draft 2.

Hasil penelitian terhadap pengembangan perangkat pembelajaran sebagaimana telah diuraikan sebelumnya, diarahkan untuk menjawab rumusan masalah dan pencapaian tujuan penelitian yaitu memperoleh perangkat pembelajaran yang valid. Menurut Van den Akker dkk. (2002) bahwa perangkat pembelajaran yang dikembangkan dikatakan berkualitas jika telah memenuhi kriteria validitas. Perangkat pembelajaran dikatakan valid ditinjau dari isi dan konstruksi yang mengacu pada karakterisktik model pembelajaran, dikatakan praktis apabila perangkat tersebut mudah dan dapat dilaksanakan, dan dikatakan efektif apabila tujuan pembelajaran dapat tercapai melalui penggunaan perangkat pembelajaran yang dikembangkan (Nieveen, 1999).

Penilaian terhadap perangkat pembelajaran berbasis model pembelajaran pemaknaan dilakukan oleh tim ahli untuk menilai setiap komponen perangkat pembelajaran yang telah dikembangkan oleh peneliti. Hasil validasi ahli yang telah diuraikan pada hasil penelitian menunjukkan bahwa semua perangkat pembelajaran yang divalidasi (buku siswa, RPP, LKPD, dan angket sensitivitas moral) tergolong kategori sangat valid. Perangkat pembelajaran yang dikembangkan telah memenuhi salah satu kriteria perangkat pembelajaran yang berkualitas seperti yang dikemukakan oleh Nieveen (1999) yaitu dikatakan valid ditinjau dari isi dan konstruksi yang mengacu pada karakterisktik model pembelajaran.

Penilaian maupun saran-saran dari ahli memberikan gambaran bahwa hasil penelitian berupa produk perangkat pembelajaran berbasis model pembalajaran pemaknaan telah memperkuat temuan-temuan sebelumnya yang berkaitan dengan pengembangan perangkat pembelajaran berbasis model pembelajaran pemaknaan, misalnya Sudiyono dkk. (2015) yang mengembangkan perangkat pembelajaran model pemaknaan untuk melatihkan sensitivitas moral siswa SMP, Sartika (2011) yang mengembangkan perangkat pembelajaran fisika berbasis model pembelajaran pemaknaan untuk meningkatkan hasil belajar siswa, Yuliani dkk. (2012) yang menerapkan model pembelajaran pemaknaan untuk mengembangkan karakter siswa SMK. Berdasarkan hasil-hasil penelitian tersebut dapat dikatakan bahwa perangkat pembelajaran materi ikatan kimia berbasis model pembelajaran pemaknaan yang telah dikembangkan ini memperkaya perangkat pembelajaran kimia dan merupakan perangkat pembelajaran materi ikatan kimia yang pertama kali menggunakan model pembelajaran pemaknaan untuk melatihkan sensitivitas moral siswa.

\section{DAFTAR PUSTAKA}

Budiningsih, Asri. (2004). Belajar dan Pembelajaran. Yogyakarta: Rineka Cipta.

Hamidi, F., Bagherzadeh, Z., Gafarzadeh, S. (2010). The Role of Islamic Education in Mental Health. Social and Behavioral Sciences. 5 : 1991-1996.

Ismail M. (2013). Educational Strategies to Develop Discipline Among Students from the Islamic Perspectives. Evaluation of Learning for Performance Improvement International Conference. Social and Behavioral Sciences. $107: 80-87$.

Kemendiknas. (2010). Pengembangan Pendidikan Budaya dan Karakter Bangsa. Jakarta: Puskur-Balitbang. Kemendiknas.

Kemendikbud. (2012). Panduan Integrasi Pendidikan Karakter dalam Pembelajaran IPA di Sekolah Dasar. Jakarta: Kementrian Pendidikan dan Kebudayan.

Nieveen, N. (1999). Prototyping to Reach Product Quality. London: Kluwer Academic Plubisher. 
Ormrod, J. E. (2002). Psikologi Pendidikan. Jakarta: Erlangga. hlm 270.

Pertiwiningrum, A., Ibrahim, M., Rahayu, Y. S (2013). Implementasi Perangkat Pembelajaran Berkarakter Berorientasi Model Pembelajaran Pemaknaan Untuk Melatihkan Sikap Moral Siswa. Surabaya: Jurnal Pendidikan Sains Universitas Negeri Surabaya. Vol. 2, No. 2:240-249.

Prastowo, A. (2011). Panduan Kreatif Membuat Bahan Ajar Inovatif. Yogyakarta: Diva Press.

Sartika, S. B. (2011). Pengembangan Perangkat Pembelajaran Fisika Berorientasi Model Pembelajaran Pemaknaan untuk Meningkatkan Hasil Belajar Siswa. Jurnal Pedagogia. Vol. 1, No. 1.

Sudiyono, A. H., Widodo, W., Susantini, E. (2015). Pengembangan Perangkat Pembelajaran Model Pemaknaan pada Materi Gelombang dan Bunyi untuk Melatihkan Sensitivitas
Moral Siswa SMP. Jurnal Pendidikan Sains UNS. Vol 5, No. 1.

Sumarni., Tukiran., Yuanita, L. 2012. Penerapan Model Pembelajaran Pemaknaan pada Materi Titrasi Asam Basa untuk Mengembangkan Karakter Siswa Kelas XI SMA. Jurnal Pendidikan Sains Pascasarjana Universitas Negeri Surabaya. Vol. 1, No. 2:85-86.

Van den Akker, J., McKenney, S., Nieveen, N. 2002. Computer Support for Curriculum Developers: CASCADE. ETR\&D. 50(4):2535

Yuliani, N., Tukiran., Yuanita, L. 2012. Penerapan Model Pembelajaran Pemaknaan Pada Pembelajaran Kimia Terhadap Pengembangan Karakter Pada Siswa SMK. Surabaya: Jurnal Pendidikan Sains Pascasarjana Universitas Negeri Surabaya. Vol. 1, No. 2:8 